Please cite this paper as follows: Verleye, Katrien, Paul Gemmel and Deva Rangarajan (forthcoming), "Engaged Customers as Job Resources or Demands for Frontline Employees," Journal of Service Theory and Practice.

\title{
Engaged Customers as Job Resources or Demands for Frontline Employees?
}

\section{Katrien Verleye}

Post-Doctoral Researcher - Center for Service Intelligence - Department Innovation, Entrepreneurship \& Service Management at Ghent University (Tweekerkenstraat 2, Ghent 9000, Belgium), phone: (0032) 926434 94, e-mail: katrien.verleye@ugent.be.

\section{Paul Gemmel}

Associate Professor, Center for Service Intelligence - Department Innovation, Entrepreneurship \& Service Management at Ghent University (Tweekerkenstraat 2, Ghent 9000, Belgium), phone: (0032) 926435 18, e-mail: paul.gemmel@ugent.be.

\section{Deva Rangarajan}

Associate Professor, Department Marketing at Vlerick Business School (Reep 2, Ghent 9000, Belgium), phone: (0032) 921092 03, e-mail: deva.rangarajan@ vlerick.com.

\section{Acknowledgment}

The authors would like to thank Bart Larivière and Patrick Van Kenhove (Ghent University), Annouk Lievens (University of Antwerp), and Valarie Zeithaml (University of North Carolina at Chapel Hill) for reviewing and giving comments to this paper. Additionally, the authors would like to thank two anonymous reviewers and the editor for their comments and suggestions.. 


\title{
Engaged Customers as Job Resources or Demands for Frontline Employees?
}

\begin{abstract}
Purpose - This paper proposes and empirically tests a theoretical model on how different customer engagement behaviors (CEBs), such as giving feedback and helping other customers, affect the role stress-job strain relationship among frontline employees.
\end{abstract}

Design/methodology/approach - Drawing from the job demands-resources model, this paper hypothesizes that some CEBs weaken the role stress-job strain relationship among frontline employees, whereas the opposite holds for other CEBs. To test these hypotheses, the study involved a survey among 279 frontline employees in 20 nursing home teams in Belgium.

Findings - The results reveal that the impact of role stress on job strain is stronger when frontline employees notice more helping behaviors among customers and weaker when frontline employees receive more customer feedback or notice that customers spread positive word of mouth about the nursing home.

Originality/value - This research contributes to the customer engagement and frontline employee literature by showing that CEBs can act as both job demands and job resources for frontline employees.

Keywords Customer engagement behaviors, frontline employees, role stress, job strain, job demands-resources model, nursing homes

Paper type Research paper 


\section{Introduction}

Firms increasingly introduce practices to encourage customer engagement with the firm and its stakeholders. Consider, for example, new product and service development platforms (e.g., www.MyStarbucksIdea.com, where customers can post new product and service ideas), reward programs (e.g., Bank of America paying customers for referrals), and customer communities (e.g., Weight Watchers meetings, in which people give and get advice on losing weight) (Brodie et al., 2011; Park et al., 2013; Verleye et al., 2014). In these examples, firms encourage customers to show engagement behaviors, such as giving feedback, spreading positive word of mouth, or helping other customers. Prior research has labeled these voluntary, discretionary, helpful behaviors with a brand or firm focus as "customer engagement behaviors," or CEBs (van Doorn et al., 2010; Verleye et al., 2014).

In recent years, practices to encourage CEBs have gained importance because researchers and practitioners have associated CEBs with improved service quality and better customer experiences and, thus, better value outcomes for customers (Fang et al., 2008; Payne et al., 2008). Firms might also derive value from CEBs, because these behaviors are likely to generate deeper and more meaningful customer-firm connections (Brodie et al., 2013; Kumar et al., 2010) as well as productivity and efficiency gains for the firm (Hoyer et al., 2010). Although researchers and practitioners have mainly focused on the implications of CEBs for customers and firms, it is conceivable that CEBs also affect frontline employees. The impact of CEBs on frontline employees deserves further investigation because frontline employees' well-being might also affect customer and firm outcomes (Garma and Bove, 2011; Hartline and Ferrell, 1996). Previous research had shown that frontline employees are likely to experience job strain because of their boundary-spanning role between the expectations of the firm and the expectations of the customer (Bateson et al., 2014; Crosno et al., 2009; Rod and Ashill, 2009). By spending a considerable amount of time interacting with customers, 
frontline employees are likely to notice CEBs and, consequently, be affected by these behaviors. Therefore, this research centers on the impact of CEBs on frontline employees' job strain, defined as an aversive, potentially harmful psychological reaction to work-related stress (Ashill and Rod, 2011; Crosno et al., 2009).

To date, research on the impact of customer behaviors on frontline employees' job strain has mainly focused on negative customer behaviors (e.g., verbal aggression), thereby hinting that these behaviors have a negative impact on job strain among frontline employees (Karatepe et al., 2010; Rafaeli et al., 2012; Rod and Ashill, 2013). In addition, a few studies have demonstrated that the same goes for customer behaviors required for service delivery, such as customers providing information about their needs (Chan et al., 2010; Hsieh and Yen, 2005; Mustak et al., 2013). Studies centered on the impact of discretionary, voluntary, helpful customer behaviors, such as CEBs, on frontline employees are scarce. Notable exceptions include Garma (2010) and Yi et al. (2011) studies, which show that voluntary customer behaviors can have a positive impact on psychological job outcomes among frontline employees. Because the impact of CEBs on frontline employees' job strain remains unclear, this research aims to provide insight into how CEBs affect frontline employees' job strain.

A wealth of job strain literature identifies role stress as the main driver of job strain among frontline employees. In addition, research on the impact of role stress on job strain among frontline employees has shown that not only personal resources (e.g., optimism) but also job resources (e.g., coworker support) can buffer the role stress-job strain relationship (Ralston et al., 2010; Rod and Ashill, 2009; Singh, 2000; Stamper and Johlke, 2003). Although this line of research has paid ample attention to different types of job resources, extant research does not go beyond job resources provided by coworkers, supervisors, and/or the organization. In other words, research does not clarify whether CEBs can buffer the role stress-job strain relationship by acting as job resources for frontline employees. 
Therefore, the main purpose of this research is to propose a theoretical framework and empirically investigate the impact of CEBs on the role stress-job strain relationship. This research contributes to the service literature in two important ways. First, by providing insight into the implications of CEBs for frontline employees, this research extends the CEB literature, which, to date, has mainly focused on the implications of CEBs for firms and their customers. Second, by investigating whether CEBs function as job resources or job demands for frontline employees, this study also contributes to frontline employee literature. Because the results reveal that CEBs can function as both job resources and job demands, and thus act as a double-edged sword for frontline employees, this research also advances service practice by proposing two strategies to ensure that frontline employees benefit, or at least do not suffer, from CEBs.

In the next section, we present the theoretical framework and hypotheses, followed by a discussion of the research methods and the results of the empirical study in the nursing home sector. We conclude with a discussion of the implications of the results for researchers and practitioners. We also acknowledge the limitations of the study, thereby identifying future research opportunities.

\section{Theoretical framework and hypotheses}

\section{Different forms of customer engagement behaviors}

Customer engagement reflects customers' interactive, cocreative experiences with firms and/or their stakeholders, which have cognitive, emotional, and behavioral manifestations (Brodie et al., 2011). This research focuses on the behavioral manifestations of customer engagement, or CEBs. Although CEBs can be negative (e.g., customers expressing their displeasure with a firm by organizing public actions against a firm), this research focuses solely on positive CEBs, which are engagement behaviors that are not intended to harm the firm and/or its stakeholders (van Doorn et al., 2010). In this study, CEBs refer to helpful, 
voluntary, discretionary customer behaviors with a brand or firm focus. The CEB literature proposes that customers can have different motives to engage in these behaviors (Jaakkola and Alexander, 2014; van Doorn et al., 2010). Moreover, customers can target different actors (e.g., the firm, its employees, other customers) with CEBs (e.g., Brodie et al., 2011; Verleye et al., 2014). From the aforementioned description, CEBs overlap with customer voluntary performance (CVP) and customer citizenship behaviors (CCBs), which are defined as, respectively, "helpful, discretionary behaviors of customers that support the ability of the firm to deliver service quality" (Bettencourt, 1997, p. 384) and "voluntary and discretionary behaviors that are not required for the successful production and/or delivery of the service but that, in the aggregate, help the service organization overall" (Groth, 2005, p. 11). In summary, CVP and CCBs are voluntary, helpful behaviors targeted at firms, their employees, and other customers (e.g., Bove et al., 2009; Groth, 2005; Rosenbaum and Massiah, 2007). Moreover, CVP, CCBs, and CEBs have been labeled as "extra-role behaviors," in that these behaviors go beyond customer role expectations (see, respectively, Bettencourt, 1997; Yi et al., 2011; van Doorn et al., 2010).

Because, conceptually, CVP, CCBs, and CEBs overlap, we reviewed the CEB, CCB, and CVP literature to identify different behavioral manifestations of customer engagement (see Table 1). The studies shown in Table 1 involve various behavioral manifestations of customer engagement. These studies also use diverse labels to capture similar behavioral manifestations of customer engagement. In addition, this review shows that behavioral expressions of CEBs overlap with CCBs and CVP. All behavioral manifestations of customer engagement, however, can be grouped into two categories: (1) CEBs with firms and/or employees and (2) CEBs in customer-to-customer interactions. Next, we categorized the CEBs with firms and/or their employees as either "cooperation" (i.e., customers showing benevolent acts to facilitate service exchanges) or "giving feedback" (i.e., customers providing information for product 
and service improvements or innovations). The CEBs observed in customer-to-customer interactions can be categorized as "helping other customers" (i.e., customers helping other customers have better service experiences) or "spreading positive word of mouth" (i.e., customers saying positive things about the firm and its employees or making recommendations to other customers). ${ }^{1}$ In the next subsection, we draw on the job demandsresources (JD-R) model to elaborate on how the four forms of CEBs delineated here affect frontline employees.

Insert Table 1 about here.

\section{Job resources as a buffer for the impact of role stress on job strain}

According to the JD-R model, risk factors associated with job strain in any occupation and across organizational contexts act as either job demands or job resources (Bakker and Demerouti, 2007; Schaufeli et al., 2009). Job demands refer to "those physical, psychological, social, or organizational aspects of the job that require sustained physical and/or psychological (cognitive and emotional) effort or skills and are therefore associated with certain physiological and/or psychological costs," while job resources refer to "physical, physiological, social, and organizational aspects of the job that are either/or: functional in achieving work goals; reduce job demands and the associated physiological and psychological costs; stimulate personal growth, learning and development" (Bakker and Demerouti, 2007, p. $312)$.

\footnotetext{
${ }^{1}$ Some researchers also create subcategories ("helping other customers" [Rosenbaum \& Massiah 2007]) or differ in their emphasis (giving feedback to the firm vs. giving feedback to frontline employees). Because the current study is among the first to investigate the impact of CEBs on frontline employees, we opted for a broader categorization, thereby building on the CEB literature (see Table 1).
} 
A first premise of the JD-R model is that job resources (e.g., social support from coworkers) increase job-related well-being through motivation, whereas job demands (e.g., job insecurity) decrease job-related well-being through job strain (Demerouti et al., 2001; Schaufeli et al., 2009). The literature on frontline employees indicates that the most important driver of job strain is stress related to the role fulfilled at work, or role stress (e.g., Ashill and Rod, 2011; Crosno et al., 2009; Rod and Ashill, 2009; Singh, 2000). Role stress, which encompasses role ambiguity (the perception of unclear role expectations), role conflict (the perception of different role expectation among multiple sources), and role overload (the perception of overwhelming role demands relative to available role resources), is thus the most important job demand for frontline employees (Rod and Ashill, 2009; Singh, 2000).

A second premise of the JD-R model is that the development of job strain depends on the interaction between job demands and job resources (Demerouti et al., 2001). Specifically, the JD-R model proposes that job resources may buffer the impact of job demands on strain, especially when job demands are high (Bakker and Demerouti, 2007). Although extant research has mainly focused on job control and social support from coworkers and/or supervisors as job resources to buffer the role stress-job strain relationship (e.g., Carlson and Perrew, 1999; Rod and Ashill, 2009; Singh, 2000), the JD-R model leaves room for the integration of other job resources. This research posits that the impact of role stress on job strain might also depend on support from customers in the form of CEBs. In the next section, we theorize about the conditions under which CEBs buffer the role stress-job strain relationship and thus act as job resources, as opposed to job demands, for frontline employees, thereby extending the JD-R model.

\section{CEBs as job resources or demands for frontline employees}

Although CEBs are assumed to benefit the firm and/or its stakeholders, this section proposes that the degree to which CEBs act as job resources, as opposed to job demands, for frontline 
employees depends on the degree to which frontline employees notice CEBs and the particular form of CEBs. Next, we develop hypotheses on the impact of each form of CEB on the role stress-job strain relationship among frontline employees (see Figure 1).

Insert Figure 1 about here.

Helping other customers implies that customers try to generate better service experiences for other customers (Kumar et al., 2010). By doing so, customers do work that resembles the work of frontline employees (Garma and Bove, 2011). In other words, customers take over tasks from frontline employees by helping one another. Because customers take over tasks from frontline employees, we suggest that customers who are helping one another participate in organizational processes and act as "partial employees" (Bowen, 1986). Previous research has shown that customers acting as partial employees can cause job strain among frontline employees because customer participation in organizational processes creates a loss of power and control among frontline employees (Bowen, 1986; Chan et al., 2010). Hsieh and Yen (2005) confirm that frontline employees might experience difficulties in controlling or predicting the behaviors of customers if they participate in the service delivery processes. Moreover, customer participation in organizational processes can generate uncertainty about task performance and heighten job strain among frontline employees because customers' dispositions to participate vary (Hsieh and Yen, 2005) and the work left undone for frontline employees might vary across customers (Chan et al., 2010; Chowdhury and Endres, 2010). Finally, some evidence shows that customers who participate in organizational processes do not necessarily perform well (Etgar, 2008). Customers can, for example, unintentionally give wrong information to other customers. From this evidence, helping-other-customer behaviors 
are likely to strengthen the impact of role stress on job strain among frontline employees and thus act as job demands for frontline employees.

H1. The effect of role stress on job strain among frontline employees is stronger when frontline employees notice more rather than less helping-othercustomer behaviors.

Customers who show cooperation behaviors also act as partial employees because these behaviors involve customer participation in organizational processes (Bowen, 1986). Specifically, customers participate in organizational processes by facilitating service exchanges and showing benevolent acts to help frontline employees. Because frontline employees - and not other customers - are the target of cooperation (van Doorn et al., 2010), we argue that these behaviors are less likely to generate a loss of power and control among frontline employees than other customer helping behaviors. Compared with helping-othercustomer behaviors, frontline employees can more easily redirect and use cooperation behaviors to their advantage. As a result, cooperation behaviors are likely to reduce the workload of frontline employees (Mills et al., 1983). Moreover, frontline employees have more time to engage in social interactions with customers who collaborate with them, which is likely to further increase the effectiveness of frontline employees (Homburg and Furst, 2007; Yi et al., 2011). Frontline employees might even build a relationship with customers who cooperate with them, which enables them to satisfy their social needs and consequently increases job engagement among frontline employees (Chan et al., 2010). As a result, frontline employees are likely to perceive customers who cooperate with them as job resources, which implies that these behaviors weaken the impact of role stress on job strain among frontline employees. 
H2. The effect of role stress on job strain among frontline employees is weaker when employees perceive more rather than less cooperation from customers.

If customers are giving feedback to the firm and its employees, they are also participating in organizational processes. Specifically, these customers participate in organizational processes by providing information for product and service improvements or new products and services. As a result, this form of customer participation is restricted to providing information, which represents a lower level of customer participation in organizational processes (Claycomb et al., 2001). Because giving feedback represents a lower level of customer participation, customer feedback behaviors are less likely to disrupt the organizational routines of frontline employees. Moreover, frontline employees might welcome customer feedback, in that this information not only facilitates improving and innovating product and service offerings (Graf, 2007) but also helps frontline employees better understand customers' needs and expectations (Wirtz et al., 2010). A good understanding of these needs and expectations helps frontline employees deliver better service quality (Parasuraman et al., 1985). If customers provide information about their needs and expectations on their own initiative, they also help frontline employees deliver service quality more efficiently (Kumar et al., 2010). Because balancing service quality and productivity is a critical part of their job (Singh, 2000), frontline employees might perceive customer feedback behaviors as job resources. In other words, customer feedback behaviors are likely to weaken the impact of role stress on job strain among frontline employees.

H3. The effect of role stress on job strain among frontline employees is weaker when employees believe that they receive more rather than less feedback from their customers. 
Positive word-of-mouth behaviors mainly occur in customer-to-customer interactions (Nambisan and Baron, 2010), though customers can also address positive word of mouth directly to frontline employees (Yi et al., 2011). Customers who are spreading positive word of mouth, either in customer-to-customer interactions or in interactions with frontline employees, do not need to participate in organizational processes to show these behaviors. As a result, these behaviors are unlikely to disrupt the organizational routines of frontline employees, which are an important driver of job strain among frontline employees (Bowen and Jones, 1986; Chan et al., 2010; Chowdhury and Endres, 2010). Conversely, frontline employees who notice these behaviors might consider positive word of mouth a form of recognition, which is an important driver of job satisfaction and, thus, job engagement among frontline employees (Sawyer, 1992). As a result, frontline employees who notice positive word-of-mouth behaviors among their customers are likely to perceive these behaviors as job resources, thus weakening the role stress-job strain relationship.

H4. The effect of role stress on job strain among frontline employees is weaker when employees notice more positive word-of-mouth behaviors among their customers.

\section{Methods}

\section{Sample and procedure}

Previous research suggests that customers are more willing to engage in the creation of value, and thus exhibit CEBs, if they have long-term relationships with the firm (Alam, 2002). Long-term customer-firm relationships are likely to exist in nursing homes because these institutions are responsible for the daily care of a limited number of customers 24 hours a day and customers typically reside in these institutions for a long time (Wang, 2013). These institutions often rely on teams for the provision of care, in that teams are responsible for the delivery of care and services for nursing home residents (Buljac-Samardzic et al., 2012). 
Therefore, data for this study come from the frontline employees of 20 nursing home teams in Belgium, which were similar in size (15-30 members) and type of provided services (services for elderly people with mental and/or physical deficiencies). Study respondents included not only nursing personnel (e.g., nurses, nursing aides, nursing managers) but also other frontline employees (e.g., physiotherapists, occupational therapists, logistics staff). In other words, all frontline employees in the teams could participate in the study.

The respondents filled out a questionnaire and deposited their questionnaire in a closed envelope in a drop box at a central location in the nursing home. The cover letter indicated that the questionnaire was designed to measure how they experienced their job and assured them that all responses would remain confidential. Of the 394 distributed questionnaires, 279 usable questionnaires were returned, for a total response rate of $71 \% .^{2}$

In line with the composition of nursing home teams, the respondent group was predominantly female (91\%) and consisted mainly of nursing aides (37\%) and nurses (28\%), followed by logistics personnel (14\%), occupational and physiotherapists (11\%), and team managers $(9 \%)$. On average, team members had 11 years tenure $(\mathrm{SD}=9.52)$.

\section{Measures}

Role stress consists of three role stressors: role ambiguity, role conflict, and role overload. Frontline employees responded to three role ambiguity and five role conflict items from the scales of Rizzo et al. (1970) and three role overload items from Beehr et al. (1976), using multi-item seven-point Likert scales ( 1 = "strongly disagree," 7 = "strongly agree"). These three role stressor scales are widely accepted measures of role stress and have high construct validity (Ashill and Rod, 2011; Crosno et al., 2009; Ortqvist and Wincent, 2010). After

\footnotetext{
${ }^{2}$ A meeting with the managers and/or head nurses of the participating nursing home teams was scheduled to explain the purpose of the research and the incentive for the nursing home (i.e., an organization-specific research report). Next, we also scheduled a second meeting with the managers and/or head nurses to pick up all the questionnaires. This method encouraged nursing home managers and/or head nurses to motivate their team members to fill out the questionnaire, thereby generating a high response rate.
} 
recoding the reversed items, Cronbach's alpha coefficients for role ambiguity, role conflict, and role overload were, respectively, $.92, .81$, and .87 . Internal consistency was satisfactory, so further analyses use mean scores.

To measure the four forms of CEBs - specifically, (1) cooperation, (2) giving feedback, (3) helping other customers, and (4) spreading positive word of mouth-from the frontline employee perspective, we followed Netemeyer et al. (2003) procedure to develop seven-point Likert scales $(1=$ "strongly disagree," $7=$ "strongly agree"). The first step involved generating items. A literature review-specifically, the scales of Bettencourt (1997), Groth (2005), and Yi and Gong (2013) — generated items to capture the four forms of CEBs. Because these items measured CEBs from the customer perspective, phrases such as "I make constructive suggestions to this organization to improve its service" were replaced by "Nursing home residents make constructive suggestions to this organization to improve its service" to ensure correspondence to existing CEB research. By doing so, this research builds on the procedure of Verleye et al. (2014), who also focus on measuring CEBs from the frontline employee perspective in nursing homes. The second step involved interviews with five frontline employees to gain insight into the face and content validity of these items, which resulted in minor adjustments to improve item clarity (for the items of the four CEB scales included in the final questionnaire, see Table 2). The third step involved a pretest of the CEB scales by means of a self-administered questionnaire among frontline employees in 10 nursing home teams, which resulted in 128 usable questionnaires. An exploratory factor analysis (principal axis factoring with oblique rotation) extracted four factors with eigenvalues greater than one, which corresponded with the four CEBs in the literature review. Finally, we assessed the four-dimensional structure among the 279 frontline employees in the main study using confirmatory factor analysis (CFA).The CFA generated acceptable goodness-of-fit statistics $\left(\chi_{(59)}^{2}=112.97\right.$, comparative fit index $=.98$, Tucker-Lewis index $=$ 
.98 , root mean square error of approximation $=.06$, standardized root mean square residual $=$ .04). All item loadings, composite reliabilities, and average variance extracted also demonstrated convergent validity (see Table 2). In addition, the sample showed discriminant validity because the square root of the average variances extracted for the CEBs exceeded the correlation between the factors (Fornell and Larcker, 1981). Therefore, further analyses use mean scores for the CEBs.

Insert Table 2 about here.

The stress and strain literature uses different scales to capture job strain (Chowdhury and Endres, 2010). The questionnaire captured job strain using three items from Maslach and Jackson (1981) emotional exhaustion scale, which is in line with empirical studies focusing on the strain process among frontline employees in health care organizations (e.g., Garrosa et al., 2011). Frontline employees responded to the items by indicating the frequency with which they experienced the state described in the items ( 1 = "never," 7 = "every day"). Because Cronbach's alpha coefficient of this scale was an acceptable .83 , further analyses use the mean score of these items.

Frontline employees provided information on role stress, CEBs, and job strain, which can result in common method variance. In line with Podsakoff et al. (2003) recommendations, this study reduces the potential for common method bias by (1) using measures based on existing scales or a careful construction of the items, (2) proximally separating measures of predictors and criterion variables, and (3) protecting respondents' anonymity by allowing them to deposit the anonymous questionnaires in a closed envelope in a drop box. In addition, a Harmon's single-factor test using exploratory factor analysis checked whether a single factor emerged or one general factor accounted for the majority of the covariance among the 
measures. The results showed eight factors. The first factor accounted for $23.41 \%$ of the variance, and all factors together explained $76.72 \%$ of the variance. Thus, none of these factors accounted for the majority of the covariance among the items, indicating that common source bias is not a serious threat to the analyses (Podsakoff et al., 2003).

Finally, the questionnaire also included gender as a control variable $(0=$ male, $1=$ female $)$ because previous research has shown that men are less susceptible to stress and strain than women (e.g., Jamal and Baba, 1992). Because organizational tenure can also have a negative relationship to strain-related variables (e.g., Chowdhury and Endres, 2010), the questionnaire included tenure as a control variable, which was measured as the number of years the respondent had been employed in the organization. Finally, the questionnaire included customer contact frequency as a control variable $(0=$ low customer contact frequency, $1=$ high customer contact frequency). Because existing measures of customer contact frequency have limitations (see Kellogg and Chase, 1995), frontline employees were asked to indicate which function they fulfilled in the nursing home, resulting in five functions (team managers, nurses, nursing aides, therapists, and logistics personnel). High customer contact frequency characterizes nurses, nursing aides, and therapists, who continuously interact face-to-face with customers. Conversely, low customer contact frequency characterizes logistics personnel and team managers because these employees have face-to-face interactions with customers but not all the time.

\section{Results}

Table 3 provides an overview of the descriptive statistics and correlations for the study variables, showing positive correlations between the three role stressors (role ambiguity, role conflict, and role overload) and job strain among frontline employees. Because the data display a hierarchical structure with frontline employees nested within teams, an unconditional hierarchical linear model for job strain provided estimates for the amount of 
variance at the individual and team levels. These estimates allowed for the calculation of the intraclass correlation (ICC). The ICC is .07 , indicating that only a small portion of the variance in job strain ratings is related to team membership. Because of this small portion of variance, we used general linear models to test the hypotheses. For each of the hypotheses, we needed to create interaction terms. Before doing so, however, we centered the independent variables, in line with the recommendations of Aiken and West (1991). This research tested the hypotheses by adding the control variables in the first step, the independent variables in the second step, and the interaction terms in the third step (see Table 4).

As Table 4 shows, the results of the analyses indicate that the control variables do not have an impact on job strain. In other words, the level of job strain does not depend on gender, tenure, or customer contact frequency.

Insert Table 3 and 4 about here.

H1 predicts that the degree to which frontline employees notice helping behaviors among customers moderates the relationship between role stress and job strain, such that the relationship is significantly more positive when the perceived level of helping behaviors among customers is high rather than low. The interaction term in the regression equation for the relationship between role conflict and helping other customers is significant $(\beta=.20, p<$ .05). As Figure 2 shows, this interaction effect supports H1. Simple slope results confirm that role conflict is positively related to job strain for frontline employees who notice high levels of helping behaviors among customers $(\beta=.35, p<.05)$, whereas role conflict is not significantly related to job strain for frontline employees who notice low levels of helping behaviors among customers $(\beta=.27, p>.05)$. In summary, the results provide support for $\mathrm{H} 1$. 
Insert Figure 2 about here.

$\mathrm{H} 2$ predicts that the degree to which frontline employees notice cooperation behaviors moderates the relationship between role stress and job strain, such that the relationship is significantly more positive when the perceived level of cooperation is low rather than high. The results, however, do not provide support for $\mathrm{H} 2$, because the interaction effects are not significant. In other words, cooperation behaviors do not affect the role stress-job strain relationship.

H3 predicts that the degree to which frontline employees notice feedback behaviors moderates the role stress-job strain relationship, such that the relationship is significantly less positive when the perceived level of feedback behaviors is high rather than low. The interaction term in the regression equation representing the relationship between role overload and giving feedback is significant $(\beta=-.23, p<.05)$. As Figure 3 shows, this interaction effect is in line with the hypothesized interaction effect. Simple slope results confirm that role overload is not significantly related to job strain for frontline employees who notice high levels of feedback behaviors $(\beta=.15, p>.05)$, but role overload is positively related to job strain for frontline employees who notice low levels of feedback behaviors $(\beta=.62, p<.01)$. Thus, the interaction effect supports H3.

Insert Figure 3 about here.

$\mathrm{H} 4$ predicts that the degree to which frontline employees notice positive word-of-mouth behaviors moderates the relationship between role stress and job strain, such that the relationship is significantly more positive when the perceived level of positive word-of-mouth 
behaviors is low rather than high. The results indicate that the interaction effect is significant; the impact of role ambiguity on job strain depends on the perceived level of positive word-ofmouth behaviors $(\beta=-.21, p<.05)$. As Figure 4 shows, this interaction effect supports H4. Simple slope results confirm that role ambiguity is positively related to job strain for frontline employees who notice low levels of positive word-of-mouth behaviors $(\beta=.50, p<.01)$, but role ambiguity is not significantly related to job strain for frontline employees who notice high levels of positive word-of-mouth behaviors $(\beta=.06, p>.05)$. In summary, these results provide support for $\mathrm{H} 4$.

Insert Figure 4 about here.

\section{Discussion}

The purpose of this study was to empirically test a theoretical framework that clarifies the implications of CEBs for frontline employees in nursing homes. The results of the analyses indicate that CEBs can function as both job demands and job resources for frontline employees, in that some CEBs strengthen the role stress-job strain relationship and other CEBs weaken it. In our hypotheses, we predicted identical effects of CEBs on the relationship between different role stressors and job strain, thereby drawing on the JD-R model (Bakker and Demerouti, 2007; Schaufeli et al., 2009). The results, however, indicate that the impact of CEBs on the role stress-job strain relationship is not identical for role ambiguity, role conflict, and role overload. In this section, we further elaborate on this issue for each CEB.

Frontline employees in nursing homes perceive customers who are helping one another as job demands; role stress was more positively related to job strain for frontline employees who noticed higher rather than lower levels of helping behaviors among customers. Specifically, the results reveal that helping-other-customer behaviors act as a job demand by strengthening 
the relationship between role conflict and job strain among frontline employees. This finding suggests that frontline employees who observe helping behaviors among customers are reminded that their role as boundary spanner does not allow them to meet all expectations of all customers, because they also need to meet the expectations of the organization (Crosno et al., 2009; Wetzels et al., 1999). Another explanation is that frontline employees perceive helping-other-customer behaviors as an indication of the lack of adequate staffing, thereby generating job strain among frontline employees. Regarding cooperation, the results of our analyses show that this type of CEB does not have a buffering impact on the role stress-job strain relationship. This finding suggests that the impact of role stress on job strain does not depend on the degree to which frontline employees notice cooperation behaviors. One possible explanation is that some nursing home residents are willing but unable to cooperate because of physical and/mental deficiencies, and as a result, frontline employees are not affected by these cooperation behaviors. Another possible explanation is that frontline employees perceive cooperation behaviors as in-role behaviors rather than as extra-role or engagement behaviors. Bendapudi and Leone (2003) confirm that patient cooperation during and after the encounter is required for the successful delivery of health care services. If cooperation behaviors are perceived as in-role rather than extra-role behaviors, these behaviors might act as antecedents to role stress rather than as moderators of the role stressjob strain relationship.

The research findings indicate that customers who engage in giving feedback act as job resources for frontline employees in nursing homes, in that feedback behaviors buffer the positive impact of role stress on job strain. Specifically, the results indicate that feedback behaviors weaken the positive impact of role overload on job strain. This finding implies that customer feedback helps frontline employees deal with overwhelming role demands. As mentioned previously, frontline employees fulfill a boundary-spanning role in that they need 
to deliver service quality in an efficient way (Crosno et al., 2009; Singh, 2000; Wetzels et al., 1999). As such, frontline employees may benefit from customers who engage in giving feedback. In other words, customer feedback helps frontline employees understand customer needs better and faster. This suggestion is in line with innovation literature, which specifies that listening to customer feedback helps generate better customer experiences while also controlling costs (Hoyer et al., 2010).

Finally, the results show that positive word-of-mouth behaviors have the potential to buffer the positive impact of role stress on job strain. In other words, the results confirm that positive word-of-mouth behaviors serve as job resources for frontline employees. Specifically, positive word-of-mouth behaviors act as job resources by weakening the positive impact of role ambiguity on job strain among frontline employees. In other words, frontline employees who notice positive word-of-mouth behaviors seem to experience less confusion about how to fulfill their roles, which confirms the reasoning that these engagement behaviors serve as a form of recognition for frontline employees and therefore serve as job resources rather than job demands for frontline employees (Sawyer, 1992).

\section{Managerial implications}

From a managerial perspective, this research indicates that not only team managers but also employees can provide job resources (i.e., supervisor and coworker support). Customers can also act as job resources by showing CEBs. The degree to which CEBs act as job resources for frontline employees, however, depends on the degree to which frontline employees notice these CEBs as well as the form of CEBs. Because the research findings indicate that some CEBs act as job resources and others as job demands, firms should use two strategies to manage CEBs.

The first strategy involves encouraging resourceful CEBs (i.e., giving feedback and spreading positive word-of-mouth behaviors). By making the organization more accessible to 
customers and encouraging customers to give feedback, firms can easily gather service improvement ideas that fit with customers' needs. Similarly, firms might also benefit from positive word-of-mouth behaviors beyond the reputational benefits, in that these CEBs buffer the positive impact of role stress on job strain among frontline employees. Because firms can encourage these types of CEBs by providing service quality, encouraging positive word-ofmouth behaviors generates both better service experiences for the customer and less job strain for frontline employees. Frontline employees might also support one another by sharing the occurrence of positive word-of-mouth behaviors in the organization. Finally, managers can introduce systems to share positive word-of-mouth behaviors (e.g., compliments) with frontline employees because these behaviors serve as a form of recognition for frontline employees.

The second strategy involves managing CEBs that act as job demands (i.e., helping-othercustomer behaviors). For helping-other-customer behaviors, frontline employees recognize that customers want to help one another but do not perceive this form of CEB as a job resource. Instead, this form of CEB acts as a job demand for frontline employees. As a result, firms might try to discourage helping-other-customer behaviors (e.g., providing behavioral guidelines for customers). It is also conceivable, however, that active and open discouragement of helping-other-customer behaviors could have unintended consequences for the firm and its stakeholders. Therefore, firms might prefer instead to offer better support for their employees in managing and coping with helping-other-customer behaviors to turn these CEBs into job resources for frontline employees. More adequate staffing levels might also help frontline employees deal with helping-other-customer behaviors because frontline employees might perceive these CEBs as an indication of a lack of adequate staffing.

In summary, the research findings suggest that managers should not view CEBs as either categorically beneficial or threatening for frontline employees, because some CEBs act as job 
resources while others act as job demands. Instead, this research suggests that firms should carefully consider the type of CEB in determining their strategy to manage CEBs. Moreover, the strategies to manage CEBs have implications for customer relationship management (Verhoef et al., 2010). Previous research merely suggests that CEB management strategies can help build stronger customer-firm relationships (Kumar et al., 2010; van Doorn et al., 2010). In the health care sector, customer relationship management is particularly important in that it brings different benefits (e.g., greater patient satisfaction) to health care organizations (Wang, 2013). As the evidence shows, health care firms might derive several benefits from carefully managing CEBs, from greater patient satisfaction to stronger customer-firm relationships.

\section{Limitations and implications for further research}

Although the tested models explain a large proportion of the variance in job strain among frontline employees (with $R^{2}$ values ranging between .33 and .35 ), the three role stressors are still the most important predictors of job strain among frontline employees. Frontline employees' role stress and job strain, however, are affected by CEBs. Further research should investigate whether CEBs have a different impact on the role stress-job strain relationship if actual CEBs were measured rather than perceived CEBs. Next, we opted for a broad conceptualization of CEBs, in that we grouped different behavioral manifestations of customer engagement into four categories (see Table 1). Additional research could investigate the impact of subcategories of the four CEBs on the role stress-job strain relationship among frontline employees (for various subcategories of the four types of CEBs in Table 1, seeRosenbaum and Massiah (2007) Bove et al. (2009) Garma and Bove (2011). Specifically, research might benefit from focusing on different subcategories of cooperation (e.g., social support, courtesy) in different settings because our findings suggest that the boundaries between voluntary and discretionary cooperation and required cooperation are blurred. 
Research could also focus on the difference between giving feedback to and spreading positive word of mouth about the firm and doing so about the employees because we do not make this distinction in this research. Research could also investigate whether different forms of CEBs can affect role stressors among frontline employees because significant correlations exist between CEBs and role stressors (see Table 3). Because a cross-sectional design does not allow researchers to draw conclusions about causality, research might benefit from a longitudinal design to investigate the relationships among CEBs, role stressors, and job strain.

In addition, further research might benefit from focusing on the process by which the relationship between different role stressors and job strain is strengthened or weakened by CEBs because we did not measure mediating variables. Research could also investigate interrelationships between job resources provided by (members of) the organization and job resources provided by customers in the form of CEBs. The degree to which CEBs buffer the impact of role stressors on job strain, for example, might also depend on the degree to which frontline employees receive support from their supervisors and/or coworkers. In other words, job and/or sector conditions might affect the degree to which CEBs are perceived as job resources or job demands. As a result, further research should focus on the boundary conditions according to which CEBs are perceived as job resources or demands. Researchers might investigate these issues with scenario-based surveys among frontline employees. These types of surveys might also shed light on how the type of information provided by customers (information about their own needs vs. information for service improvement) affects role stress and job strain among frontline employees.

Because the current study sample was limited to 279 frontline employees in teams that were similar in size and type of provided services, further research might also investigate whether the impact of CEBs on job strain among frontline employees depends on the size or the type of services provided by the team to which the frontline employees belong. Research 
could also control for other team characteristics, such as the climate and culture in the team. Finally, research should explore whether the results are generalizable to other sectors because this study gathered all the empirical evidence in the nursing home sector.

Our research focused on nursing home residents and, thus, direct customers (i.e., customers who directly consume nursing home services). Previous research, however, has shown that indirect customers (e.g., family members, nursing home residents) also play an important role (Verleye et al., 2014). As a result, research might also investigate how CEBs of indirect customers (e.g., family members of nursing home residents) affect frontline employees.

\section{References}

Aiken, L. S. and West, S. G. (1991), Multiple regression: Testing and interpreting interactions, Sage Publications, New York

Alam, I. (2002), "An exploratory investigation of user involvement in new service development", Journal of the Academy of Marketing Science, Vol. 30 No. 3, pp. 250-261.

Ashill, N. J. and Rod, M. (2011), "Burnout processes in non-clinical health service encounters", Journal of Business Research, Vol. 64 No. 10, pp. 1116-1127.

Bakker, A. B. and Demerouti, E. (2007), "The job demands-resources model: State of the art", Journal of Managerial Psychology, Vol. 22 No. 3, pp. 309-328.

Bateson, J. E. G., Wirtz, J., Burke, E. and Vaughan, C. (2014), "Psychometric sifting to efficiently select the right service employees", Managing Service Quality, Vol. 24 No. 5, pp. 418-433.

Beehr, T. A., Walsh, J. T. and Taber, T. D. (1976), "Relationship of stress to individually and organizationally valued states - higher-order needs as a moderator", Journal of Applied Psychology, Vol. 61 No. 1, pp. 41-47.

Bendapudi, N. and Leone, R. P. (2003), "Psychological implications of customer participation in coproduction", Journal of Marketing, Vol. 67 No. 1, pp. 14-28. 
Bettencourt, L. A. (1997), "Customer voluntary performance: Customers as partners in service delivery", Journal of Retailing, Vol. 73 No. 3, pp. 383-406.

Bove, L. L., Pervan, S. J., Beatty, S. E. and Shiu, E. (2009), "Service worker role in encouraging customer organizational citizenship behaviors", Journal of Business Research, Vol. 62 No. 7, pp. 698-705.

Bowen, D. E. (1986), "Managing customers as human resources in service organizations", Human Resources Management, Vol. 25 No. 3, pp. 371-383.

Bowen, D. E. and Jones, G. R. (1986), "Transaction cost analysis of service organization-customer exchange", Academy of Management Review, Vol. 11 No. 2, pp. 428-441.

Brodie, R. J., Hollebeek, L. D., Juric, B. and Illic, A. (2011), "Customer engagement: Conceptual domain, fundamental propositions, and implications for research", Journal of Service Research, Vol. 14 No. 3, pp. 252-271.

Brodie, R. J., Ilic, A., Juric, B. and Hollebeek, L. (2013), "Consumer engagement in a virtual brand community: An exploratory analysis", Journal of Business Research, Vol. 66 No. 1, pp. 105-114.

Buljac-Samardzic, M., van Woerkom, M. and Paauwe, J. (2012), "Team safety and innovation by learning from errors in long-term care settings", Health Care Management Review, Vol. 37 No. 3, pp. 280-291.

Carlson, D. S. and Perrew, P. L. (1999), "The role of social support in the stressor-strain relationship: An examination of work-family conflict", Journal of Management, Vol. 25 No. 4, pp. 513-540.

Chan, K. W., Yim, C. K. and Lam, S. S. K. (2010), "Is customer participation in value creation a double-edged sword? Evidence from professional financial services across cultures", Journal of Marketing, Vol. 74 No. 3, pp. 48-64.

Chowdhury, S. K. and Endres, N. L. (2010), "The impact of client variability on nurses' occupational strain and injury: Cross-level moderation by safety climate", Academy of Management Journal, Vol. 53 No. 1, pp. 182-198.

Claycomb, C., Lengnick-Hall, C. A. and Inks, L. W. (2001), "The customer as a productive resource: A pilot study and strategic implications", Journal of Business Strategies, Vol. 18 No. 1, pp. 47-68. 
Crosno, J. L., Rinaldo, S. B., Black, H. G. and Kelley, S. W. (2009), "Half full or half empty: The role of optimism in boundary-spanning positions", Journal of Service Research, Vol. 11 No. 3, pp. 259-309.

Demerouti, E., Bakker, A. B., Nachreiner, F. and Schaufeli, W. B. (2001), "The job demandsresources model of burnout", Journal of Applied Psychology, Vol. 86 No. 3, pp. 499-512.

Etgar, M. (2008), "A descriptive model of the consumer co-production process", Journal of the Academy of Marketing Science, Vol. 36 No. 1, pp. 97-108.

Fang, E., Palmatier, R. W. and Evans, K. R. (2008), "Influence of customer participation on creating and sharing of new product value", Journal of the Academy of Marketing Science, Vol. 36 No. 3, pp. 322-336.

Fornell, C. and Larcker, D. F. (1981), "Evaluating structural equation models with unobservable variables and measurement error", Journal of Marketing Research, Vol. 18 No. 1, pp. 39-50.

Garma, R. (2010), "Customer citizenship behaviour and its impact on service personnel's psychological job outcomes", $\mathrm{PhD}$ thesis, The University of Melbourne.

Garma, R. and Bove, L. L. (2011), "Contributing to well-being: Customer citizenship behaviors directed to service personnel", Journal of Strategic Marketing, Vol. 19 No. 7, pp. 633-649.

Garrosa, E., Moreno-Jimenez, B., Rodriguez-Munoz, A. and Rodriguez-Carvajal, R. (2011), "Role stress and personal resources in nursing: A cross-sectional study of burnout and engagement", International Journal of Nursing Studies, Vol. 48 No. 4, pp. 479-489.

Graf, A. (2007), "Changing roles of customers: Consequences for hrm", International Journal of Service Industry Management, Vol. 18 No. 5, pp. 491-509.

Groth, M. (2005), "Customers as good soldiers: Examining citizenship behaviors in internet service deliveries", Journal of Management, Vol. 31 No. 1, pp. 7-27.

Hartline, M. D. and Ferrell, O. C. (1996), "The management of customer-contact service employees: An empirical investigation", Journal of Marketing, Vol. 60 No. 4, pp. 52-70.

Homburg, C. and Furst, A. (2007), "See no evil, hear no evil, speak no evil: A study of defensive organizational behavior towards customer complaints", Journal of the Academy of Marketing Science, Vol. 35 No. 4, pp. 523-536. 
Hoyer, W. D., Chandy, R., Dorotic, M., Krafft, M. and Singh, S. S. (2010), "Consumer cocreation in new product development", Journal of Service Research, Vol. 13 No. 3, pp. 283-296.

Hsieh, A. T. and Yen, C. H. (2005), "The effect of customer participation on service providers' job stress", The Service Industries Journal, Vol. 25 No. 7, pp. 891 - 905.

Jaakkola, E. and Alexander, M. (2014), "The role of customer engagement behavior in value cocreation: A service system perspective", Journal of Service Research, Vol. 17 No. 3, pp. 247-261.

Jamal, M. and Baba, V. V. (1992), "Shiftwork and department-type related to job stress, work attitudes and behavioral intentions - a study of nurses", Journal of Organizational Behavior, Vol. 13 No. 5, pp. 449-464.

Karatepe, O., Karatepe, M., Haktanir, I. and Yorganci (2010), "The impacts of core self-evaluations on customer-related social stressors and emotional exhaustion", The Service Industries Journal, Vol. 30 No. 9, pp. 1565-1579.

Kellogg, D. L. and Chase, R. B. (1995), "Constructing an empirically derived measure for customer contact", Management Science, Vol. 41 No. 11, pp. 1734-1749.

Kumar, V., Aksoy, L., Donkers, B., Venkatesan, R., Wiesel, T. and Tillmanns, S. (2010), "Undervalued or overvalued customers: Capturing total customer engagement value", Journal of Service Research, Vol. 13 No. 3, pp. 297-310.

Maslach, C. and Jackson, S. E. (1981), "The measurement of experienced burnout", Journal of Occupational Behaviour, Vol. 2 No. 2, pp. 99-113.

Mills, P. K., Chase, R. B. and Margulies, N. (1983), "Motivating the client employee system as a service production strategy", Academy of Management Review, Vol. 8 No. 2, pp. 301-310.

Mustak, M., Jaakkola, E. and Halinen, A. (2013), "Customer participation and value creation: A systematic review and research implications", Managing Service Quality, Vol. 23 No. 4, pp. 341359.

Nambisan, S. and Baron, R. A. (2010), "Different roles, different strokes: Organizing virtual customer environments to promote two types of customer contributions", Organization Science, Vol. 21 No. 2, pp. 554-572. 
Netemeyer, R. G., Bearden, W. O. and Sharma, S. (2003), Scaling procedures. Issues and applications, Sage Publications, Thousand Oaks.

Ortqvist, D. and Wincent, J. (2010), "Role stress, exhaustion, and satisfaction: A cross-lagged structural equation modeling approach supporting hobfoll's loss spirals", Journal of Applied Social Psychology, Vol. 40 No. 6, pp. 1357-1384.

Parasuraman, A., Zeithaml, V. A. and Berry, L. L. (1985), "A conceptual model of service quality and its implications for future research", Journal of Marketing, Vol. 49 No. 4, pp. 41-50.

Park, S. B., Chung, N. and Woo, S. C. (2013), "Do reward programs build loyalty to restaurants? The moderating effect of long-term orientation on the timing and types of rewards", Managing Service Quality, Vol. 23 No. 3, pp. 225-244.

Payne, A. F., Storbacka, K. and Frow, P. (2008), "Managing the co-creation of value", Journal of the Academy of Marketing Science, Vol. 36 No. 1, pp. 83-96.

Podsakoff, P. M., MacKenzie, S. B., Lee, J.-Y. and Podsakoff, N. P. (2003), "Common method biases in behavioral research: A critical review of the literature and recommended remedies", Journal of Applied Psychology, Vol. 88 No. 5, pp. 879-903.

Rafaeli, A., Erez, A., Ravid, S., Derfler-Rozin, R., Treister, D. E. and Scheyer, R. (2012), "When customers exhibit verbal aggression, employees pay cognitive costs", Journal of Applied Psychology, Vol. 97 No. 5, pp. 931-950.

Ralston, D. A., Lee, C. H., Perrewe, P. L., Van Deusen, C., Vollmer, G. R., Maignan, I., Tang, M., Wan, P. and Rossi, A. M. (2010), "A multi-society examination of the impact of psychological resources on stressor-strain relationships", Journal of International Business Studies, Vol. 41 No. 4, pp. 652-670.

Rizzo, J. R., House, R. J. and Lirtzman, S. I. (1970), "Role conflict and ambiguity in complex organizations", Administrative Science Quarterly, Vol. 15 No. 2, pp. 150-162.

Rod, M. and Ashill, N. J. (2009), "Symptoms of burnout and service recovery performance the influence of job resourcefulness", Managing Service Quality, Vol. 19 No. 1, pp. 60-84.

Rod, M. and Ashill, N. J. (2013), "The impact of call centre stressors on inbound and outbound callcentre agent burnout", Managing Service Quality, Vol. 23 No. 3, pp. 245-264. 
Rosenbaum, M. S. and Massiah, C. A. (2007), "When customers receive support from other customers - exploring the influence of intercustomer social spupport on customer voluntary performance", Journal of Service Research, Vol. 9 No. 3, pp. 257-270.

Sawyer, J. E. (1992), "Goal and process clarity - specification of multiple constructs of role ambiguity and a structural equation model of their antecedents and consequences", Journal of Applied Psychology, Vol. 77 No. 2, pp. 130-142.

Schaufeli, W. B., Bakker, A. B. and Van Rhenen, W. (2009), "How changes in job demands and resources predict burnout, work engagement, and sickness absenteeism", Journal of Organizational Behavior, Vol. 30 No. 7, pp. 893-917.

Singh, J. (2000), "Performance productivity and quality of frontline employees in service organizations", Journal of Marketing, Vol. 64 No. 2, pp. 15-34.

Stamper, C. L. and Johlke, M. C. (2003), "The impact of perceived organizational support on the relationships between boundary spanner role stress and work outcomes", Journal of Management, Vol. 29 No. 4, pp. 569-588.

van Doorn, J., Lemon, K. N., Mittal, V., Nass, S., Pick, D., Pirner, P. and Verhoef, P. C. (2010), "Customer engagement behavior: Theoretical foundations and research directions", Journal of Service Research, Vol. 13 No. 3, pp. 253-266.

Verhoef, P. C., Reinartz, W. J. and Krafft, M. (2010), "Customer engagement as a new perspective in customer management", Journal of Service Research, Vol. 13 No. 3, pp. 247-252.

Verleye, K., Gemmel, P. and Rangarajan, D. (2014), "Managing engagement behaviors in a network of customers and stakeholders: Evidence from the nursing home sector", Journal of Service Research, Vol. 17 No. 1, pp. 68-84.

Wang, M. L. (2013), "Implementing crm in nursing homes: The effects on resident satisfaction", Managing Service Quality, Vol. 23 No. 5, pp. 388-409.

Wetzels, M., De Ruyter, K. and Lemmink, J. (1999), "Role stress in after-sales service management", Journal of Service Research, Vol. 2 No. 50, pp. 50-67. 
Wirtz, J., Tambyah, S. K. and Mattila, A. S. (2010), "Organizational learning from customer feedback received by service employees: A social capital perspective", Journal of Service Management, Vol. 21 No. 3, pp. 363-387.

Yi, Y. and Gong, T. (2013), "Customer value co-creation behavior: Scale development and validation", Journal of Business Research, Vol. 66 No. 9, pp. 1279-1284.

Yi, Y., Nataraajan, R. and Gong, T. (2011), "Customer participation and citizenship behavioral influences on employee performance, satisfaction, commitment, and turnover intention", Journal of Business Research, Vol. 64 No. 1, pp. 88-96. 


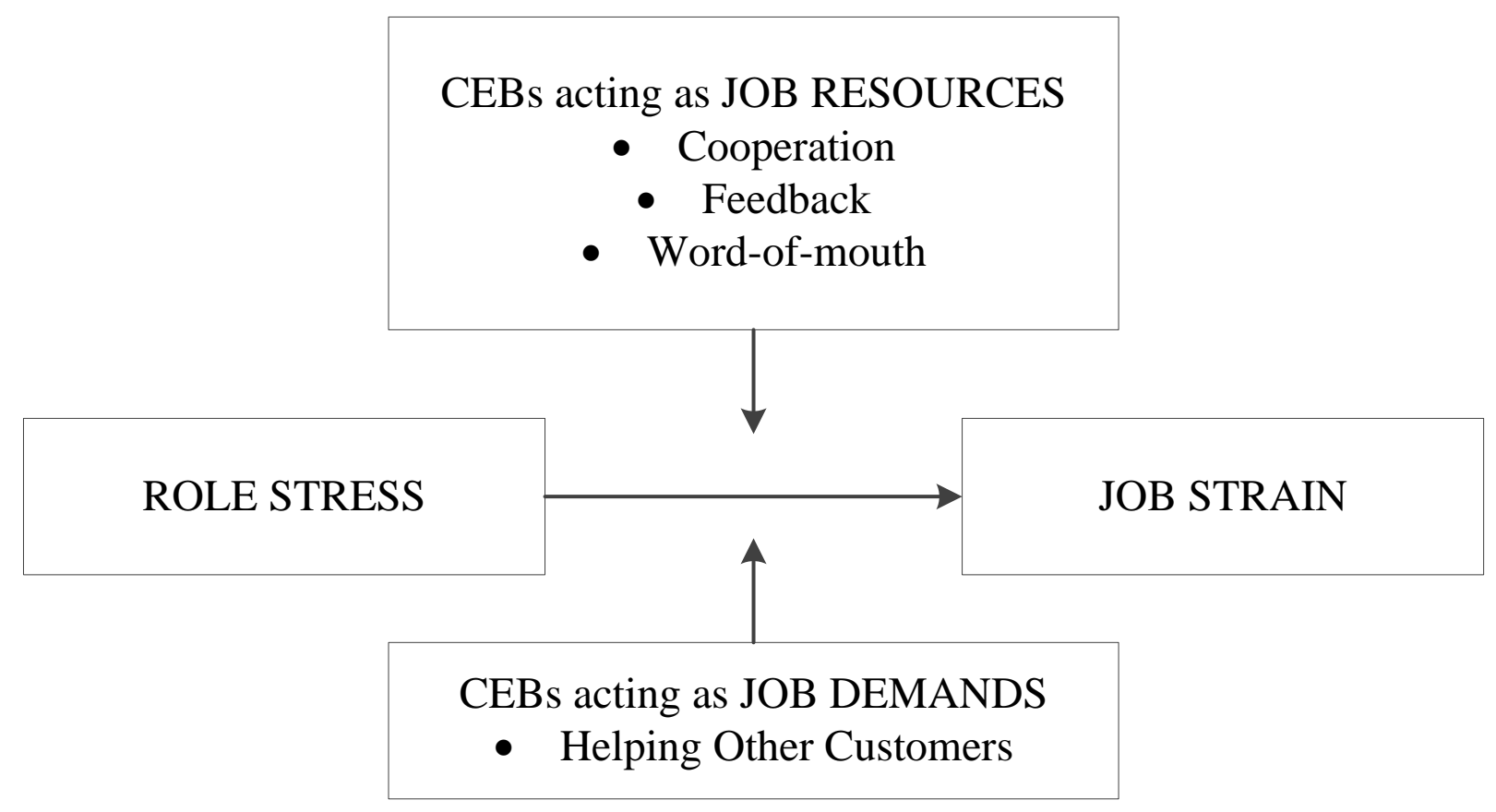

Figure 1. Theoretical Model for Impact of Customer Engagement Behaviors (CEBs) on the Strain Process among Frontline Employees. 


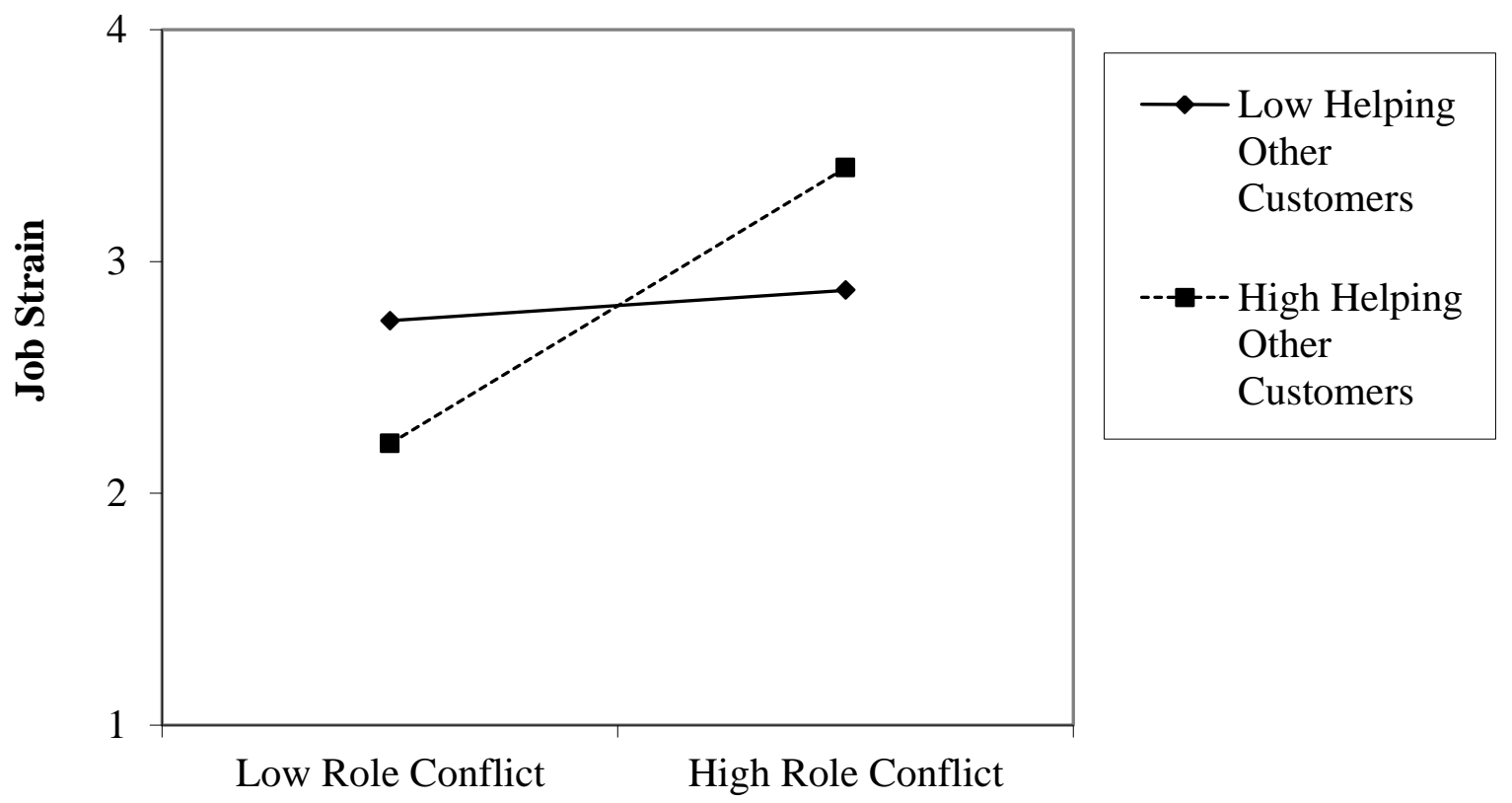

Figure 2. The Moderating Effect of Helping Other Customers on the Strain Process. 


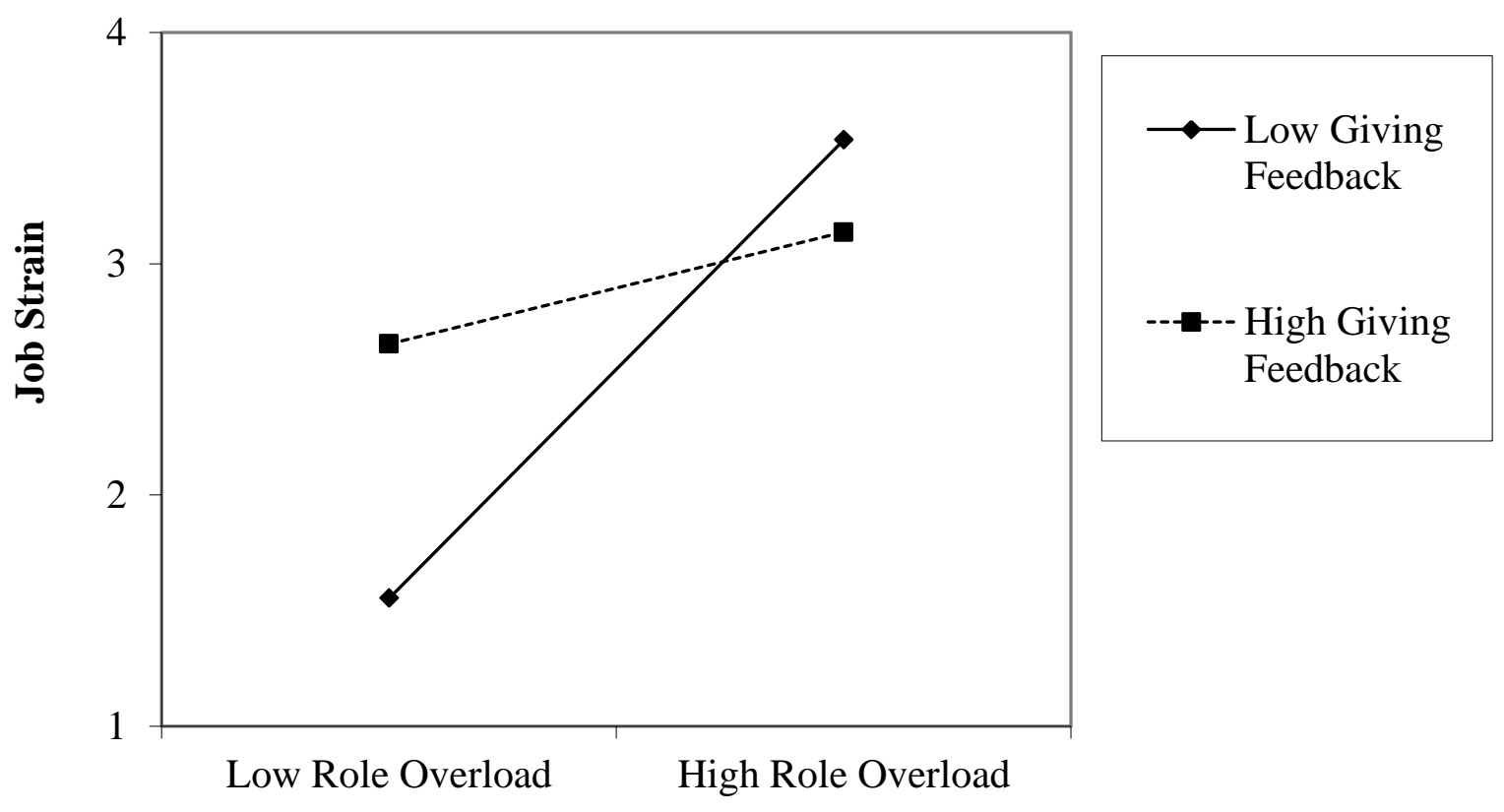

Figure 3. The Moderating Effect of Giving Feedback on the Strain Process. 


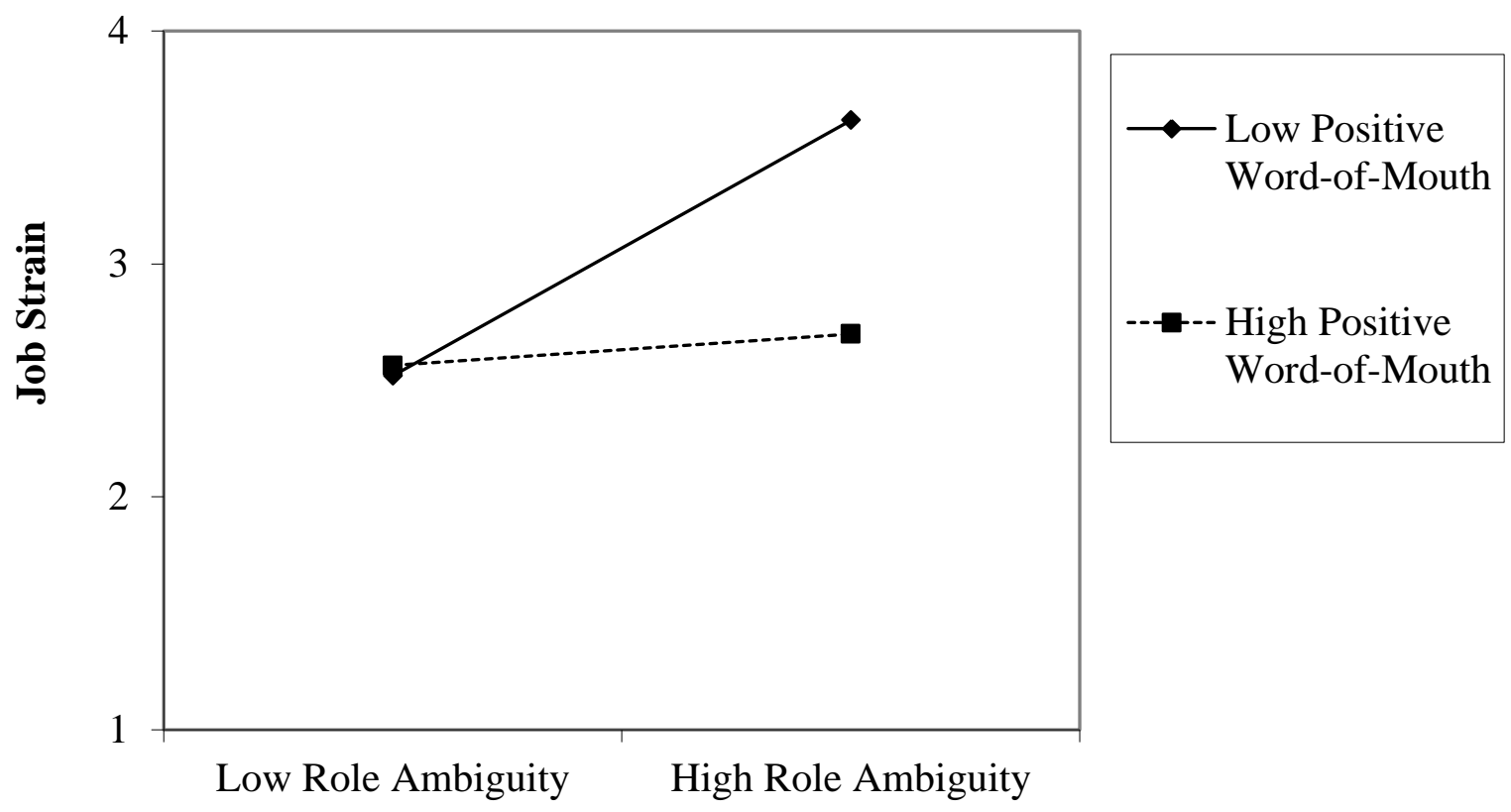

Figure 4. The Moderating Effect of Positive Word-of-Mouth Behaviors on the Strain Process. 


\section{Table 1}

Different Forms of Customer Engagement Behaviors.

\begin{tabular}{|c|c|c|c|c|c|}
\hline & & \multicolumn{2}{|c|}{ CEBs in interactions with the firm and its employees } & \multicolumn{2}{|c|}{ CEBs in customer-to-customer interactions } \\
\hline & & COOPERATION & GIVING FEEDBACK & HELPING OCs & POSITIVE WORD-OF-MOUTH \\
\hline \multirow[t]{3}{*}{$\begin{array}{l}\text { CEB } \\
\text { literature }\end{array}$} & $\begin{array}{l}\text { CEBs * } \\
\text { (Kumar et al., } \\
2010)\end{array}$ & & $\begin{array}{l}\text { customer knowledge behavior } \\
\text { giving feedback to the firm for ideas } \\
\text { for innovations and improvements, } \\
\text { and contributing to knowledge } \\
\text { development }\end{array}$ & $\begin{array}{c}\text { customer influencer } \\
\text { behavior } \\
\text { sharing information with and } \\
\text { assisting other customers } \\
\text { post acquisition }\end{array}$ & $\begin{array}{l}\text { customer influencer behavior } \\
\text { providing word-of-mouth } \\
\text { recommendations } \\
\text { customer referral behavior } \\
\text { current customers converting } \\
\text { prospects in their social network } \\
\text { (both online and offline) into } \\
\text { actual customers for which they } \\
\text { are rewarded }\end{array}$ \\
\hline & $\begin{array}{l}\text { CEBs } \\
\text { (e.g., van Doorn et } \\
\text { al., 2010) }\end{array}$ & $\begin{array}{c}\text { helping and coaching service } \\
\text { providers }\end{array}$ & $\begin{array}{l}\text { making suggestions to improve the } \\
\text { consumption experience }\end{array}$ & $\begin{array}{l}\text { helping other customers to } \\
\text { consume better }\end{array}$ & $\begin{array}{l}\text { recommendations } \\
\text { positive word-of-mouth }\end{array}$ \\
\hline & $\begin{array}{l}\text { CEBs in a } \\
\text { multistakeholder } \\
\text { system } \\
\text { (Jaakkola and } \\
\text { Alexander, 2014) }\end{array}$ & $\begin{array}{l}\text { augmenting behavior } \\
\text { adding to the focal firm's } \\
\text { offering beyond transactions }\end{array}$ & $\begin{array}{l}\text { codeveloping behavior } \\
\text { facilitating the development of the } \\
\text { offerings of the focal firm }\end{array}$ & $\begin{array}{l}\text { augmenting behavior } \\
\text { adding to the focal firm's } \\
\text { offering beyond transactions }\end{array}$ & $\begin{array}{c}\text { influencing behavior } \\
\text { affecting people's perceptions of } \\
\text { the focal firm } \\
\text { mobilizing behavior } \\
\text { mobilizing people to show } \\
\text { benevolent acts to focal firm }\end{array}$ \\
\hline \multirow[t]{2}{*}{$\begin{array}{l}\text { CCB } \\
\text { literature }\end{array}$} & $\begin{array}{l}\text { CC } \\
(\text { e.g., Groth, 2005) }\end{array}$ & & providing feedback & helping other customers & making recommendations \\
\hline & $\begin{array}{l}\text { COCBs } \\
\text { (Bove et al., 2009) }\end{array}$ & $\begin{array}{c}\text { benevolent acts of service } \\
\text { facilitation } \\
\text { charitable customer acts } \\
\text { within immediate service } \\
\text { exchange } \\
\text { flexibility } \\
\text { willingness to adapt to } \\
\text { situations beyond their control }\end{array}$ & $\begin{array}{c}\text { customer voice } \\
\text { directing complaints to service } \\
\text { providers to give them the } \\
\text { opportunity to correct problems } \\
\text { suggestions for service } \\
\text { improvement } \\
\text { providing ideas/suggestions not } \\
\text { derived from specific instances of } \\
\text { consumption dissatisfaction } \\
\text { participation in the firm's activities }\end{array}$ & $\begin{array}{l}\text { policing of other customers } \\
\text { observing other customer } \\
\text { behaviors and reacting to } \\
\text { these behaviors to ensure } \\
\text { that appropriate behaviors } \\
\text { occur }\end{array}$ & $\begin{array}{c}\text { positive word of mouth } \\
\text { favorable, informal, person-to- } \\
\text { person communication between a } \\
\text { perceived non-commercial } \\
\text { communicator and a receiver } \\
\text { regarding an object or issue } \\
\text { display of relationship } \\
\text { affiliation } \\
\text { communicating to other } \\
\text { customers about their } \\
\text { relationship with a firm } \\
\end{array}$ \\
\hline
\end{tabular}




\begin{tabular}{|c|c|c|c|c|c|}
\hline & & COOPERATION & GIVING FEEDBACK & HELPING OCs & POSITIVE WORD-OF-MOUTH \\
\hline \multirow[t]{4}{*}{$\begin{array}{l}\text { CCB } \\
\text { literature }\end{array}$} & $\begin{array}{l}\text { CCBs directed to } \\
\text { service personnel } \\
\text { (Garma, 2010; } \\
\text { Garma and Bove, } \\
\text { 2011) }\end{array}$ & $\begin{array}{l}\text { assumed employee role } \\
\text { doing work that resembles the } \\
\text { work of service personnel } \\
\text { sportsmanship } \\
\text { display of flexibility and } \\
\text { tolerance associated with } \\
\text { service delivery provided by } \\
\text { service personnel }\end{array}$ & $\begin{array}{l}\text { consultancy } \\
\text { providing information to service } \\
\text { personnel with the intention of } \\
\text { improving the service offering }\end{array}$ & $\begin{array}{c}\text { assumed employee role } \\
\text { doing work that resembles } \\
\text { the work of service } \\
\text { personnel }\end{array}$ & $\begin{array}{c}\text { advocacy } \\
\text { promoting, recommending or } \\
\text { speaking on behalf or in favor of } \\
\text { service personnel }\end{array}$ \\
\hline & & $\begin{array}{l}\text { social support } \\
\text { assisting service personnel to } \\
\text { cope with stressful situations } \\
\text { or make their work more } \\
\text { enjoyable }\end{array}$ & & & \\
\hline & & $\begin{array}{c}\text { courtesy } \\
\text { friendliness, sociability, or } \\
\text { positive emotion toward } \\
\text { service personnel }\end{array}$ & & & \\
\hline & $\begin{array}{l}\text { CCBs } \\
\text { (Yi et al., 2011) }\end{array}$ & $\begin{array}{c}\text { polite and courteous } \\
\text { behaviors towards frontline } \\
\text { employees }\end{array}$ & $\begin{array}{c}\text { constructive involvement in } \\
\text { suggesting service improvements }\end{array}$ & & positive word-of-mouth \\
\hline \multirow[t]{2}{*}{$\begin{array}{l}\text { CVP } \\
\text { literature }\end{array}$} & $\begin{array}{l}\text { CVP } \\
(\text { e.g., Bettencourt, } \\
1997)\end{array}$ & $\begin{array}{c}\text { cooperation } \\
\text { discretionary customer } \\
\text { behaviors showing respect for } \\
\text { service quality provision }\end{array}$ & $\begin{array}{c}\text { participation } \\
\text { active and responsible involvement } \\
\text { in the organization's governance } \\
\text { and development }\end{array}$ & & $\begin{array}{c}\text { loyalty } \\
\text { customer behaviors indicating } \\
\text { allegiance to and promotion of } \\
\text { the organization's interests } \\
\text { beyond individual interests }\end{array}$ \\
\hline & $\begin{array}{l}\text { CVP ** } \\
\text { (Rosenbaum and } \\
\text { Massiah, 2007) }\end{array}$ & $\begin{array}{c}\text { cooperation } \\
\text { displaying courtesy to an } \\
\text { establishment's employees } \\
\text { and customers }\end{array}$ & $\begin{array}{c}\text { participation } \\
\text { offering an establishment } \\
\text { suggestion for improvement }\end{array}$ & $\begin{array}{c}\text { customer empathy to other } \\
\text { customers } \\
\text { customer responsibility to } \\
\text { other customers in a service } \\
\text { setting }\end{array}$ & $\begin{array}{l}\text { loyalty } \\
\text { spreading positive } \\
\text { word of mouth }\end{array}$ \\
\hline
\end{tabular}

Note. CEBs = customer engagement behaviors; $\mathrm{OCs}=$ other customers; $\mathrm{CC}=$ customer citizenship; COCBs = customer organizational citizenship behaviors; CCBs = customer citizenship behaviors; CVP = customer voluntary performance; * = Kumar et al. (2010) do not use the notion 'CEBs' but they describe customer knowledge behavior, customer influencer behavior, and customer referral behavior as 'behavioral manifestations of customer engagement'; ** $=$ cooperation, participation and loyalty are also labeled as 'customer citizenship', while customer empathy and customer responsibility are labeled as customer care by Rosenbaum \& Massiah (2007). 


\section{Table 2}

CFA Results for CEB Scales.

Constructs and Items Factor Loading

Helping other customers $(C R=.92 ; A V E=.79)$

NHRs assist other customers in finding their way within the nursing home

NHRs help other customers if necessary

NHRs explain to other customers which services are provided by the organization

Cooperation $(C R=.86 ; A V E=.67)$

NHRs do things to make the personnel's job easier

Employees of this nursing home get full cooperation from NHRs

NHRs try to help the service provider to deliver the best possible treatment

Giving feedback $(C R=.83 ; A V E=.55)$

NHRs let this organization know of ways to better serve their needs

NHRs inform nursing home personnel if they experience a problem

NHRs make constructive suggestions to this organization to improve its service 0.83

NHRs give useful ideas to the nursing home personnel

Positive word-of-mouth $(C R=.95 ; A V E=.86)$

NHRs recommend this nursing home to people interested in nursing homes

NHRs recommend this nursing home to family and friends

NHRs say positive things about this nursing home to others

0.98

Note. NHRs = nursing home residents; $C R=$ composite reliability; $A V E=$ average variance extracted. 


\section{Table 3}

Means, Standard Deviations, Cronbach's Alpha, and Correlation Matrix.

\begin{tabular}{|c|c|c|c|c|c|c|c|c|c|c|c|}
\hline Constructs & $M$ & $S D$ & $\begin{array}{c}\text { Cronbach's } \\
\text { Alpha }\end{array}$ & 1 & 2 & 3 & 4 & 5 & 6 & 7 & 8 \\
\hline 1. Role ambiguity & 2.87 & 1.10 & .92 & 1.00 & & & & & & & \\
\hline 2. Role conflict & 4.41 & 1.18 & .81 & .05 & 1.00 & & & & & & \\
\hline 3. Role overload & 4.40 & 1.58 & .87 & -.03 & $.52 * *$ & 1.00 & & & & & \\
\hline 4. Job strain & 3.47 & 1.43 & .83 & $.15^{*}$ & $.32 * *$ & $.33 * *$ & 1.00 & & & & \\
\hline 5. Helping other customers & 4.83 & 1.12 & .92 & $-.17 * *$ & $-.15^{*}$ & -.03 & -.06 & 1.00 & & & \\
\hline 6. Cooperation & 4.51 & 1.13 & .85 & $-.13^{*}$ & $-.23 * *$ & $-.17 * *$ & $-.15^{*}$ & $.34 * *$ & 1.00 & & \\
\hline 7. Giving feedback & 4.84 & 1.03 & .83 & $-.30 * *$ & -.04 & -.01 & -.06 & $.45^{* *}$ & $.23 * *$ & 1.00 & \\
\hline 8. Positive word-of-mouth & 4.64 & 1.04 & .95 & $-.17 * *$ & $-.17 * *$ & -.05 & $-.17 * *$ & $.40 * *$ & $.44^{* *}$ & $.36^{* *}$ & 1.00 \\
\hline
\end{tabular}

Note. $M=$ mean construct score (unweighted); $S D=$ standard deviation.

$$
\begin{aligned}
& * p<.05 \\
& * * p<.01
\end{aligned}
$$




\section{Table 4}

Results of Hierarchical Regression Analyses for Job Strain.

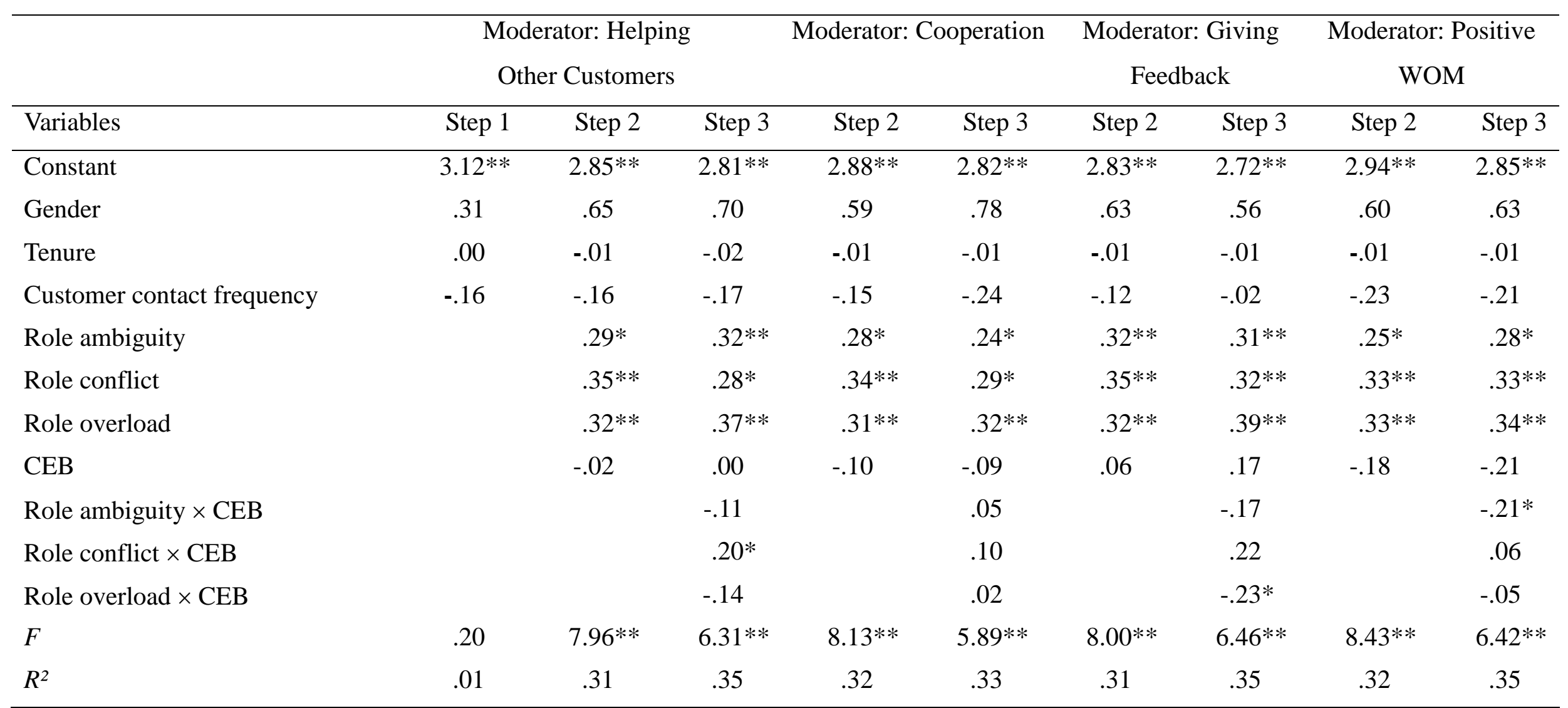

Notes. $\mathrm{CEB}=$ customer engagement behavior; $\mathrm{WOM}$ = word-of-mouth; values are unstandardized regression coefficients.

$* p<.05$

$* * p<.01$ 
